\title{
Tinjauan Teologis Terhadap Konsep Rasul Paulus Tentang "Kelemahan" Berdasarkan Surat 2 Korintus 12:1-10 Dan Implikasinya Dalam Kehidupan Orang Percaya Masa Kini
}

\author{
Jacoba Paulina Nanlohy
}

\begin{abstract}
Abstrak
Tujuan penulisan skripsi ini adalah untuk menjelaskan tentang pemahaman teologis terhadap konsep Rasul Paulus tentang kelemahan berdasarkan 2 Korintus 12:1-10 serta untuk menjelaskan implikasi praktis tentang kelemahan sesuai konsep Rasul Paulus berdasarkan 2 Korinstus 12:1-10 dalam kehidupan orang percaya masa kini. Adapun hasil penelitian dapat disimpulkan sebagai berikut: Pertama, kelemahan dapat menghindarkan manusia dari meninggikan diri supaya manusia tidak melupakan Allah dalam keberhasilan. Karena keberhasilan banyak kali membuat manusia menjadi sombong dan dengan cepat melupakan Tuhan serta cenderung membanggakan dirinya. Dengan adanya kelemahan seseorang akan menyadari bahwa kesuksesan yang dicapai itu karena pemeliharaan Allah. Kelemahan juga akan menanamkan kaki orang percaya untuk tetap melekat pada bumi dan hidup dalam kerendahan hati. Kedua, kelemahan menyatakan kecukupan kasih karunia Allah, karena dalam kelemahan seseorang akan terus berharap dan bergantung kepada Allah, dan dalam kepasrahan kepada Allah ia akan merasakan bahwa kasih karunia Allah yang besar dan cukup untuk mengatasi segala kelemahannya. Kecukupan kasih karunia Allah terbukti dan menjadi nyata disaat seseorang berada dalam kelemahan dan tidak melihat jalan keluar yang pasti. Ketiga, kelemahan diberikan Allah untuk tujuan tertentu karena dengan adanya kelemahan setiap orang akan mengerti bahwa Allah bisa mencapai tujuannya di atas kelemahan dan kerendahan hati manusia, bukan di atas kekuatan dan keyakinan pada kekuatan dirinya sendiri, dan bahwa Ia dapat memakai orang yang biasa-biasa saja dan penuh kekurangan bahkan lebih tertarik kepada orang-orang yang menyadari dan mengakui keterbatasan atau kelemahannya, supaya menjadi nyata bahwa dalam kelemahanlah kuasa Allah menjadi sempurna. Keempat, kelemahan sebagai realitas hidup yang menjadikan kuat. Oleh sebab itu setiap kelemahan harus dihadapi dengan tetap bersandar kepada Allah karena Dia akan memberikan kekuatan kepada orang percaya dan gereja-Nya untuk bertahan dan menghadapi kelemahan tanpa harus menyalahkan keadaan.
\end{abstract}


Kata-kata Kunci: Tinjauan, Teologis, Konsep, Paulus, Kelemahan, 2 Korintus 12:1-10, Implikasi, Kehidupan, Orang Percaya.

\section{Pendahuluan}

\section{Latar Belakang Masalah}

Manusia adalah makhluk yang diciptakan menurut gambar dan rupa Allah, memiliki keunikan dan berbagai kelebihan. Tidak hanya memiliki kelebihan jika dibandingkan dengan ciptaan lainnya, kelebihan yang dimiliki antara manusia yang satu dengan yang lainnya juga berbeda-beda baik dalam hal fisik, karakter dan juga kemampuan. Dan dengan kelebihan-kelebihan tersebut masing-masing orang akan menjalani kehidupannya untuk mencapai keberhasilan.

Kelebihan yang dimiliki manusia pada umumnya bisa berupa ketrampilan, bakat atau talenta, kepintaran, sifat-sifat atau kebiasaan yang baik, atau bisa juga berupa kelebihan secara fisik yang mana semuanya itu akan melengkapi manusia dalam beraktifitas, berkarya dan juga melayani Tuhan. Khusus bagi orang percaya yang hidup dalam kebenaran juga diperlengkapi Allah dengan berbagai karunia untuk melayani Dia. Bakat, talenta dan karunia-karunia yang diberikan Allah tersebut akan menjadi potensi sekaligus kelebihan yang membuat manusia menjadi pribadi yang unik yang memiliki kekhasan sendiri karena hal-hal tersebut tidak sama antara manusia yang satu dengan yang lain.

Sebagai ciptaan yang fana manusia tidak hanya memiliki kelebihankelebihan, tetapi juga memiliki kelemahan yang tentunya juga dapat memberi pengaruh dalam menjalani kehidupan. Kelemahan tersebut dapat berupa kelemahan secara mental atau pun secara fisik. Bisa juga kelemahan khusus yang terjadi atas izin Allah, karena sebuah tujuan tertentu yang harus digenapi lewat kehidupan seseorang.

Hal yang sama juga dialami oleh Paulus yang sekalipun adalah Rasul utusan Allah yang memiliki berbagai karunia dan kelebihan, tetapi juga memiliki keterbatasan manusiawi yang dapat mengganggunya dalam melakukan aktifitas kesehariannya. Dalam suratnya kepada jemaat di Korintus, Paulus menanggapi para pengajar-pengajar sesat yang berusaha mengguncangkan kepercayaan jemaat Korintus supaya meragukan kerasulannya, dengan cara menyoroti kelemahan manusiawi Paulus (2 Kor. 3:1; 10:1, 10-13; 11:5-6). Menurut William Barclay orang-orang Korintus sesungguhnya telah terlalu dalam mengejek Paulus 
mengenai penampilan pribadinya dalam hal perawakan dan mengejeknya bahwa ia lemah dan bukanlah seorang pembicara baik. ${ }^{1}$

Dalam pasal 10 sampai 13 Paulus dengan tegas memberikan pembelaan tentang kerasulannya di hadapan jemaat dan dalam pembelaan tersebut ia tidak berusaha untuk bisa menyamakan dirinya dengan orang-orang tertentu yang bermegah atas kelebihan mereka, atau bermegah atas hasil pekerjaan dari orangorang tersebut tetapi Paulus berkata "Jika aku harus bermegah, maka aku akan bermegah atas kelemahanku" (2 Kor. 11:30). Paulus sepenuhnya menyadari bahwa Allah mengizinkan ia berada dalam kelemahan untuk sebuah tujuan sehingga bagi Paulus kebanggaannya tidak ia dasarkan pada apa yang menjadi kelebihannya, tetapi pada kelemahannya. Dalam terjemahan NIV dikatakan "If I must boast, I will boast of the things that show my weakness" jika aku harus bermegah, aku akan bermegah dari ha-hal yang menunjukkan kelemahanku, ini memberi pengertian bahwa sebenarnya Paulus memiliki hal-hal yang menunjukkan kelebihan dalam dirinya, sama seperti yang dimiliki oleh orangorang yang meragukan kerasulannya. Tetapi untuk semua kelebihan ataupun kekuatan yang pernah dimilikinya telah dianggap sebagai sampah yang tidak lagi ingin dibanggakannya, selain dari kelemahan yang ada pada dirinya (Flp. 3:7-8).

Dalam pengakuannya akan adanya "duri dalam daging" yang diakuinya sebagai sebuah kelemahan, tidak membuatnya berhenti mengikuti panggilan Allah, tetapi ia justru semakin giat melakukan pelayanannya untuk memberitakan Injil Kristus. V. C. Pfitzner mengatakan, duri dalam daging yang merupakan kelemahan Rasul Paulus itu adalah sebuah penyakit jasmani, ini berdasarkan isi suratnya kepada jemaat di Galatia di mana dalam surat itu Rasul Paulus mengingat bagaimana pertama kali memberitakan Injil kepada mereka karena "sakit pada tubuhku" yang merupakan penderitaan bagi mereka pula (Gal. 4:1315). ${ }^{2}$ Hal yang sama juga dikatakan oleh William Barclay bahwa teori yang paling tua mengatakan Paulus menderita sakit kepala yang berat dan sangat menyusahkan. Teori tersebut didukung dengan teori lain yang mengatakan bahwa Paulus kesulitan melihat, dan teori inilah yang kemudian menjelaskan penyebab sakit kepala yang dialaminya. ${ }^{3}$

V. C. Pfitzner mengatakan bahwa Paulus lebih suka membanggakan diri atas penderitaannya, dari pada tanda-tanda kekuatan lahiriahnya dan dengan bermegah atas kelemahannya, Paulus justru mempermalukan mereka yang

\footnotetext{
${ }^{1}$ William Barclay, Pemahaman Alkitab Setiap Hari - Surat 1 dan 2 Korintus (Jakarta: BPK Gunung Mulia, 2015), 424.

${ }^{2}$ V. C. Pfitzner, Ulasan atas Surat 2 Korintus - Kekuatan dalam Kelemahan (Jakarta: BPK Gunung Mulia, 2007), 188.

${ }^{3}$ William Barclay, Pemahaman Alkitab Setiap Hari - Surat 1 dan 2 Korintus, 450.
} 
memamerkan kebajikan dan kekuatannya sendiri. ${ }^{4}$ Sementara Charles R. Swindoll mengatakan, jika Paulus masih hidup pada masa kini ia tidak akan menyambut ucapan selamat kita atas kekuatannya dalam menghadapi pencobaan karena bagi dia kekuatannya berasal dari merangkul kelemahan dan bermegah atas kelemahan itu. ${ }^{5}$ Teori-teori tersebut dapat membawa kita pada satu kebenaran bahwa kelemahan fisik yang dialami oleh Rasul Paulus tidak membuatnya menjadi lemah tetapi ia justru berkata "sebab jika aku lemah, maka aku kuat" (2 Kor. 12:10b). Namun demikian kelemahan yang dimaksud Paulus tidak boleh disalah artikan, karena dengan pengertian salah tentang kelemahan akan membuat orang percaya tidak memiliki perasaan bersalah dan usaha untuk meninggalkan kelemahan tersebut. Kelemahan yang dimaksud Paulus bukan berarti sebuah dosa, kemalasan atau ketidaktaatan tetapi menunjukkan sebuah kondisi yang membuat Paulus tidak dapat melakukan sesuatu apa pun karena ketidakmampuannya.

Berbeda dengan pandangan Paulus tentang kelemahan, manusia secara umum justru cenderung menganggap kelemahan adalah hal yang harus disembunyikan dan kelebihan adalah sesuatu yang sangat penting dan menjadi perhatian, khususnya dalam hal bekerja. Misalnya, dalam hal kepemimpinan duniawi, seorang pemimpin haruslah seorang yang kuat yang memiliki kelebihan dan tidak boleh menampakkan kelemahannya di depan orang-orang yang dipimpinnya. Karena bila didapati adanya kelemahan dalam diri sang pemimpin, maka hal tersebut dapat menjadi kehancuran dalam kepemimpinannya. Makanya sering terjadi seorang pemimpin akan berusaha untuk menjadi sempurna dan kuat supaya dapat menutupi dan menyangkali kelemahan yang dimilikinya. Hal yang sama juga terjadi dalam dunia pemasaran di mana sebuah produk yang akan dipasarkan selalu mengiklankan apa yang menjadi kelebihan dan keunggulan produk tersebut, sedangkan kelemahan produk sedapat mungkin akan disembunyikan.

Di dalam gereja atau persekutuan, hal-hal demikian pun sering terjadi, khususnya ketika orang menyampaikan kesaksian. Kesaksian yang biasa disampaikan umumnya tentang mukjizat, kuasa doa, keberhasilan dalam bisnis, kesehatan dan berkat Tuhan yang membuat jemaat menjadi kagum. Namun sebenarnya, orang percaya juga memiliki pengalaman kehilangan, kegagalan dan penderitaan yang sebenarnya layak untuk dibagikan. ${ }^{6}$ Karena semuanya merupakan realitas hidup yang harus dihadapi manusia dan dapat dijadikan pengalaman berharga. Dr. Julianto Simanjuntak mengatakan bahwa memang pada

\footnotetext{
${ }^{4}$ V. C. Pfitzner, Ulasan atas Surat 2 Korintus - Kekuatan dalam Kelemahan, 189.

${ }^{5}$ Charles R. Swindol, Paulus - Seorang Yang Penuh Kasih Karunia dan Tegar (Jakarta: Nafiri Gabriel, 2004), 322.

${ }^{6}$ Julianto Simanjuntak, Mengenali Monster Pribadi - Seni Pemulihan Diri Dari Trauma, Emosi Negatif Dan Kebiasaan Buruk (Jakarta: Yayasan Pelikan Indonesia, 2013), 140.
} 
umumnya manusia cenderung memakai topeng dan berusaha untuk menampilkan kelebihan dan kebaikan yang dimiliki, namun menutup rapat kelemahannya. ${ }^{7}$

Charles R. Swindol mengutip perkataan J. Oswald Sanders, di dalam bukunya Paul, The Leader, yang mengatakan,

Kita adalah bagian dari suatu generasi yang menganggungkan kekuasaan - militer, intelektual, ekonomi, ilmu pengetahuan. Konsep kuasa dijalankan dalam kehidupan kita sehari-hari. Dunia kita terbagi atas blok-blok kekuasaan. Di mana-mana manusia berjuang untuk mendapatkan kekuasaan dalam berbagai bidang, dan sering kali dengan motivasi yang dipertanyakan. ${ }^{8}$

Sementara Andrew Murray mengatakan bahwa orang Kristen perlu untuk mengakui dan mengamini kelemahannya, supaya ia mulai belajar untuk mengerti rahasia kuasa Yesus, karena terkadang keluhan mengenai kelemahan hanyalah merupakan suatu dalih bagi kemalasan kita. ${ }^{9}$

Kekuatan atau kelebihan memang adalah bagian yang selalu diusahakan untuk ditonjolkan agar manusia dapat menjalani kehidupan dengan baik dan sebaliknya apa yang dianggap sebagai sebuah kelemahan sedapat mungkin akan disembunyikan. Sementara orang-orang dunia secara umum menyembunyikan kelemahannya, Rasul Paulus justru mengatakan bahwa jika aku harus bermegah, maka aku akan bermegah atas kelemahanku (2 Kor. 11:30). Hal inilah yang membuat penulis tertarik untuk menemukan penjelasan yang benar sesuai perspektif firman Tuhan tentang kelemahan menurut pandangan Rasul Paulus.

\section{Pokok Masalah}

Berdasarkan latar belakang masalah di atas maka pokok masalah yang akan dibahas dalam penulisan skripsi ini adalah :

Pertama, bagaimana pemahaman teologis terhadap konsep Rasul Paulus tentang kelemahan berdasarkan 2 Korintus 12:1-10?

Kedua, bagaimana implikasi praktis tentang kelemahan dalam kehidupan orang percaya masa kini?

\footnotetext{
${ }^{7}$ Julianto Simanjuntak, Mengenali Monster Pribadi - Seni Pemulihan Diri Dari Trauma, Emosi Negatif, Dan Kebiasaan Buruk, 140.

${ }^{8}$ Charles R. Swindoll, Seorang Yang Penuh Kasih Karunia Dan Tegar-Paulus, 322; J. Oswald Sanders, Paul, The Leader (Grand Rapids, Mich,: NavPress, 1984), 173-174.

${ }^{9}$ Andrew Murray, Membina Iman (Bandung: Yayasan Kalam Hidup, 2001), 86.
} 


\section{Tujuan Penelitian}

Adapun tujuan penulisan skripsi ini adalah :

Pertama, untuk menjelaskan tentang pemahaman teologis terhadap konsep Rasul Paulus tentang kelemahan berdasarkan 2 Korintus 12:1-10.

Kedua, untuk menjelaskan implikasi praktis tentang kelemahan sesuai konsep Rasul Paulus berdasarkan 2 Korinstus 12:1-10 dalam kehidupan orang percaya masa kini.

\section{Manfaat Penelitian}

Adapun manfaat penulisan yang ingin dicapai melalui penulisan skripsi ini adalah:

Pertama, sebagai dasar pemikiran agar orang percaya dapat memahami bagaimana pemahaman teologis terhadap konsep Rasul Paulus tentang kelemahan berdasarkan 2 Korinstus 12:1-10?

Kedua, agar orang percaya tidak membanggakan diri dalam kelebihan serta kekuatan yang dimiliki dan menyadari bahwa dalam kelemahan pun kuasa Tuhan dapat bekerja dengan sempurna.

\section{Metode Penelitian}

Metode penulisan yang digunakan oleh penulis dalam penulisan skripsi ini adalah penulisan kualitatif dengan menggunakan prinsip-prinsip Hermeneutik, yaitu metode eksegesis. ${ }^{10}$ Penulis menggunakan teknik pengumpulan data melalui penggalian kepustakaan (library research) yaitu menggunakan Alkitab dalam berbagai cetakan, kamus, tafsiran dan buku-buku serta berbagai literatur dan tulisan di media online yang berhubungan dengan pembahasan dalam skripsi ini.

\section{Batasan Penelitian}

Dalam skripsi ini penulis hanya membahas mengenai tinjauan teologis terhadap konsep rasul paulus tentang "kelemahan" berdasarkan surat 2 Korintus 12:1-10 dan bagaiman implikasinya dalam kehidupan orang percaya masa kini.

\section{Kepustakaan}

Barclay, William. Pemahaman Alkitab Setiap Hari - Surat 1 dan 2 Korintus. Jakarta: BPK Gunung Mulia, 2015.

\footnotetext{
${ }^{10}$ Secara sederhana eksegesis adalah penafsiran yang diperoleh meneliti teks dalam Alkitab tanpa dipengaruhi oleh pandangan orang lain. Hengki Wijaya, Analisis Data Kualitatif Ilmu Pendidikan Teologi(Makassar: Sekolah Tinggi Theologia Jaffray, 2018), 95.
} 
Lesmana, H., Robi Panggarra. "Makna Bait Allah dalam 1 Korintus 3:16-17 dan Implikasinya bagi orang Percaya Masa Kini." Jurnal Jaffray 12, no. 1 (2014). http://dx.doi.org/10.25278/jj71.v12i1.35

Murray, Andrew. Membina Iman. Bandung: Yayasan Kalam Hidup, 2001.

Pfitzner, V. C. Ulasan atas Surat 2 Korintus - Kekuatan dalam Kelemahan. Jakarta: BPK Gunung Mulia, 2007.

Rande, N., Daniel Ronda. "Makna Kebangkitan Kristus Berdasarkan I Korintus 15:12-28 Dan Implikasinya Bagi Orang Percaya.” Jurnal Jaffray 11, no. 2 (2013). http://dx.doi.org/10.25278/jj71.v11i2.79

Sanders, J. Oswald. Paul, The Leader. Grand Rapids, Mich: NavPress, 1984.

Simanjuntak, Julianto. Mengenali Monster Pribadi - Seni Pemulihan Diri Dari Trauma, Emosi Negatif Dan Kebiasaan Buruk. Jakarta: Yayasan Pelikan Indonesia, 2013.

Swindol, Charles R. Paulus - Seorang Yang Penuh Kasih Karunia dan Tegar. Jakarta: Nafiri Gabriel, 2004.

Wijaya, Hengki. "Pengenaan Manusia Baru Di Dalam Kristus: Natur, Proses, Dan Fakta Serta Implikasi Teologis Dan Praktisnya." Jurnal Jaffray 14, no. 1 (2016). http://dx.doi.org/10.25278/jij1.v14i1.194

Wijaya, Hengki. Analisis Data Kualitatif: Ilmu Pendidikan Teologi. Makassar: Sekolah Tinggi Theologia Jaffray, 2018. 